\title{
ESCAPING THE RED QUEEN EFFECT THROUGH TECHNOLOGY INTELLIGENCE: A REVIEW OF THE LITERATURE AND RECOMMENDATIONS
}

\author{
Tanyel Cakmak \\ Turkish Military Academy, Turkey \\ cross $^{\text {ref }}$ http://dx.doi.org/10.5755/j01.em.19.2.6553
}

\begin{abstract}
Technological innovations and inventions can change the competitive environment by creating new business, new industries, or by demolishing the existing. Forecasting the new technologies and the new innovations can lead the organizations to be proactive and to make smart decisions. The knowledge-based and co-evolutionary business environment today, organizations should survive by running at least twice faster than their competitors, but also they should run smarter and dissimilarly. The Red Queen Effect phenomenon explains the role of the co-evolution and the speed of the competitive actions of the rivals in business environment. On the other hand, the question "how to be faster and smarter" should be answered in scope of the technological change. This article suggests the importance of Technology Intelligence to manage the firm competitiveness under the Red Queen Effect, and identifies the expected benefits of an effective Technology Intelligence activity.
\end{abstract}

The type of the article: Theoretical article.

Keywords: Technology Intelligence, Red Queen Effect, business competition, Comfort Trap.

JEL Classification: O14.

\section{Introduction}

Despite technological innovations can create new industries and transform or destroy existing ones, anticipating the direction and impact of technological change is one of the most difficult problems of technology management (Utterback \& Brown, 1972; Cooper \& Schendel, 1976). Industry and government must anticipate radical technological changes that sweep aside existing practices and open new opportunities-or create new problems. The company that neglects this task runs a serious risk (Bright, 1970).

The dynamics of environmental alterations may lead to radical changes of the foundations on which the technology strategy of a company is based. Therefore, at least, foresight of future technologies is an important part of corporate-level technology strategy of the companies (Edler, Krahmer, Reger, 2002). However the complexity and dynamism of technological development make it difficult to generate an information base relevant technological trend. Therefore, already in the 1970's, several authors called a systematic and continuous observation and evaluation of technological trends (Lichtenthaler, 2003).

Technology intelligence process is a part of technology management discipline. According to the proposed Technology Management Model based on dynamic capabilities approach, one of the core activities within technology management is "identification of technologies" which includes search, auditing, data collection and intelligence processes for technologies and markets (Cetindamar, Phaal, Probert, 2010).

The dynamic environment defined in business, economics, biology etc. is part of nature and life. Red Queen Effect is firstly adopted by Van Valen in biology to define the co-evolving populations hypothesis. The Red Queen Effect refers to the The Red Queen character in „Through the Looking Glass“ by Levis Carroll says „Now, here, you see, it takes all the running you can do, 
to keep in the same place. If you want to get somewhere else, you must run at least twice as fast as that!" (Carroll, 1872). According to Van Valen, there is a continued evolutionary change in species. If a selection experienced by two organisms of different species depends on the other species and the resulting evolutionary process occurs simultaneously in both species they co-evolve. This is Red Queen Dynamism. The fast runner organism causes the other's evolution; this evolution again causes the organism to evolve. This co-evolution process is a race between species. For example, butterflies have biochemical detoxification mechanisms against the insecticide of the plants that helps defend the plant from herbivorous insects. Only the fast runner can survive under this effect and the unimproved one dies. Natural selection acts on plants to produce new or better insecticides. And the butterfly evolves a new detoxifying mechanism (Ehrlich \& Raven, 1964). Red Queen Effect is such a race that the winner is the fast runner.

In technology, we can see the Red Queen Effect, i.e. ERA armors against shaped-charge warhead missiles. They co-evolve against each other; when ERA armor is strengthened; missiles are developed. And then armor is again strengthened as a response for the missile, and so on... Continuous innovations and new technology development is a result of Red Queen Effect on the market place.

This process in technology development as a result of competition and forecasting the next step of the evolution of the technology is vitally important for the technology developer to survive in the race. For business, technology developers should anticipate the new coming technologies to react earlier and to make decisions for the new investments, organizational changes etc. If not, it is strongly late for the reaction. This is Red Queen Effect which the business is surviving in. In that case, the question "how to give a proactive and smart reaction against the technological change?" should be answered.

At his point, technology management disciple suggests Technology Intelligence for discovering the opportunities/threats of new coming technologies and for anticipating their impacts in business/industry/market against the Red Queen Effect.

In this study, once the researches on Red Queen Effect on business competition are explored and the relation with economy, organizations and technology development is concluded. It is emphasized in this article that Technology Management discipline and Technology Intelligence has an interaction with the Red Queen by the meaning of the considered impacts on strategic decisions of the organizations. And as a result, an effective Technology Intelligence as a part of technology management activities is offered to the organizations for surviving against the Red Queen Effect.

\section{Method}

A literature review is conducted on the critical evaluations on Red Queen Effect and Technology Intelligence to determine whether both have reciprocal contingencies in scope of business competition. Technology Intelligence is a substantial topic in Technology Management literature. Red Queen Effect is discussed in the literature of Biology, Ecology, Economics and Business Competition. Electronic journal databases (i.e. Ebsco Search, Web of Knowledge, Science Direct etc.), books and symposium / conference proceedings were searched and the publications that includes the key words (technology intelligence, red queen effect, business competition) are explored. The prominent studies are included for the literature review.

\section{Red Queen Effect in Business Competition}

Revolutionary thinking in economics philosophy grew up with Adam Smith's The Wealth of Nations (1776). Adam Smith argued that self-regulating behavior of the marketplace is conducted by selfish actions of individuals that are conceptualized as ,invisible hand“. Individual in the marketplace intends only his own gain and only his own security, and his action mostly led by an invisible hand to promote an end which was no part of his intention. Such selfish actions of individuals is a result of surviving capability, and at the same time a reason of reciprocal actions between each other. A new ,evolutionary action“ created by an indiviual/or any institution provokes 
the other one, and the other one provokes the other. In economy, the balance is provided by these reciprocal actions and evolution.

Charles Darwin, the father of evolution theory, influenced by ,invisible hand“. He argued the competition between species which the ,evolution” is forced by. The economic or biologic systems has the dynamic forms of competition, therefore the theorems in these fields have borrowings from each other. They have similar questions to be answered: How do the species/firms compete? Why some species/firms are successful, and some of them fail? Both economic and biologic competition theorems, the „complex and large systems” are in question. The competitive co-evolutionary effect, saying Red Queen Effect, is observed in this type of systems. Relevantly, system actors and their competitive actions is the important subject of the earlier theories in these fields to understand the system, environment and the nature of competition as well as in business.

Schumpeter's theory of „Creative Destruction“ (1934) comprises Red Queen effect on the base. Schumpeter establishes that in competitive market place, a large firm or monopoly should develop new technologies to earn the profit by lowering the prices and introducing new product innovations. The technology competition between the firms is the main source of economic growth and also the life quality. Firms should make innovation to achieve the profit, and to survive. This is the Red Queen Effect in marketplace that Schumpeter draws attention. In Capitalism, Socialism and Democracy (1976) Schumpeter argues that firms should invent more sophisticated technologies to gain the monopolistic profit and for growing. If the firm is inactive against superior product or technology shocks and cannot create any opportunity, then it cannot achieve economic advantage during the next period. Therefore, firm should continually run and run, make innovations, introducing new products to the market. The faster runner (early contributor) wins the most profit and survives (Schumpeter, 1976).

Co-evolution in economy is discussed as economy is a web of co-evolving like an ecosystem by Kaufman (1995). According to Kaufman, new products or innovations create their niche and innovations open new areas to introduce new products, new technologies, processes etc. This effect spurs the organizations for rapid learning and acting to survive. Therefore, Red Queen Effect is connected to economic development.

Baumol (2004) concludes by arguing that the Red Queen effect is in competition within the high-tech industries of today's economies. The surviving firms cannot get the risk to fall behind its rivals, by staying abreast of the others, the firm only can hope to preserve its place in the market. According to him, the „new economy” is a result of the continuous outpouring of innovations that Red Queen Effects plays a critical role within.

Related to business competition, recently, some organizational models are developed including Red Queen effect. Barnett and Hansen (1996), Barnett \& Sorenson (2002), Barnett and McKendrick (2004), Barnett and Pontikes (2005), discussed how the organisations reacts under Red Queen Effect in order to answer the question of „Why are some organizations more competitive than others?"

Voelpel et al. (2005) suggested the „Comfort Trap of Red Queen Effect”. In an increasingly discontinuous environment, the market leader companies have a great risk of taking negative impacts of rival' actions. Comfort Trap of Red Queen Effect as the situations where established firms or incumbents - as in a comfort of being innovator and the first enterer - failed to properly respond not only to technologies, but also to competitors and the customers at the same time seemed apparently irrelevant to their respective business; and they are trapped.

\section{Red Queen Effect and Technology Management}

Technology as a major source of competitive advantage and growth for companies (Cetindamar et al., 2010; Phall, 2004) enables the organizations to compete through the changing and evolving market demand and to adapt the new market opportunities. Only the technology itself is not adequate for the firm to compete, at the same time the technology should be implemented effectively by the organization, be adapted to the strategic actions of the firm; in brief, technology 
should be managed.

Firm has many capabilities including organizational characteristics, assets, information, knowledge, etc. that are managed by the firm to design and implement of the firm' strategies to compete and to survive. Integrating the technological capabilities to the firm's strategic goals and managing these capabilities allocating the strategic and operational actions differentiate the firm from others. At this point, technology management discipline offers managing the technological capabilities to shape and accomplish the strategic and operational objective of an organization (Cetindamar et al., 2010).

In literature, there is a limited source that bounds the Red Queen and Technology Management. Dynamic capabilities based view in Technology Management could be integrated with the Red Queen Effect. As claimed by Teece et al. (1997), managerial abilities and combinations of organizational, functional and technological skills to achieve new forms of competitive advantage are dynamic capabilities of the firm. Dynamic capability appears to be particularly difficult for the firms to develop. When incumbents invest on the radical, destructive technology, they are often at a disadvantage relative to new entrants in developing new capability (Tripsas, 1997). At this position, the incumbent is in a comfort trap of Red Queen as being stable and unsuccessful to develop dynamic capability or lack of building capabilities into strategic goals of the firm. At this juncture, technology management offers interconnected activities based on technological capabilities of the firm. The technology management framework (Gregory, 1995; Phaal et al., 2004) -includes acquisition of technology, exploitation, identification, protection and selection- is embedded within firm's strategy, innovation and operations. Learning activity was added to this framework later (Cetindamar et al., 2010).

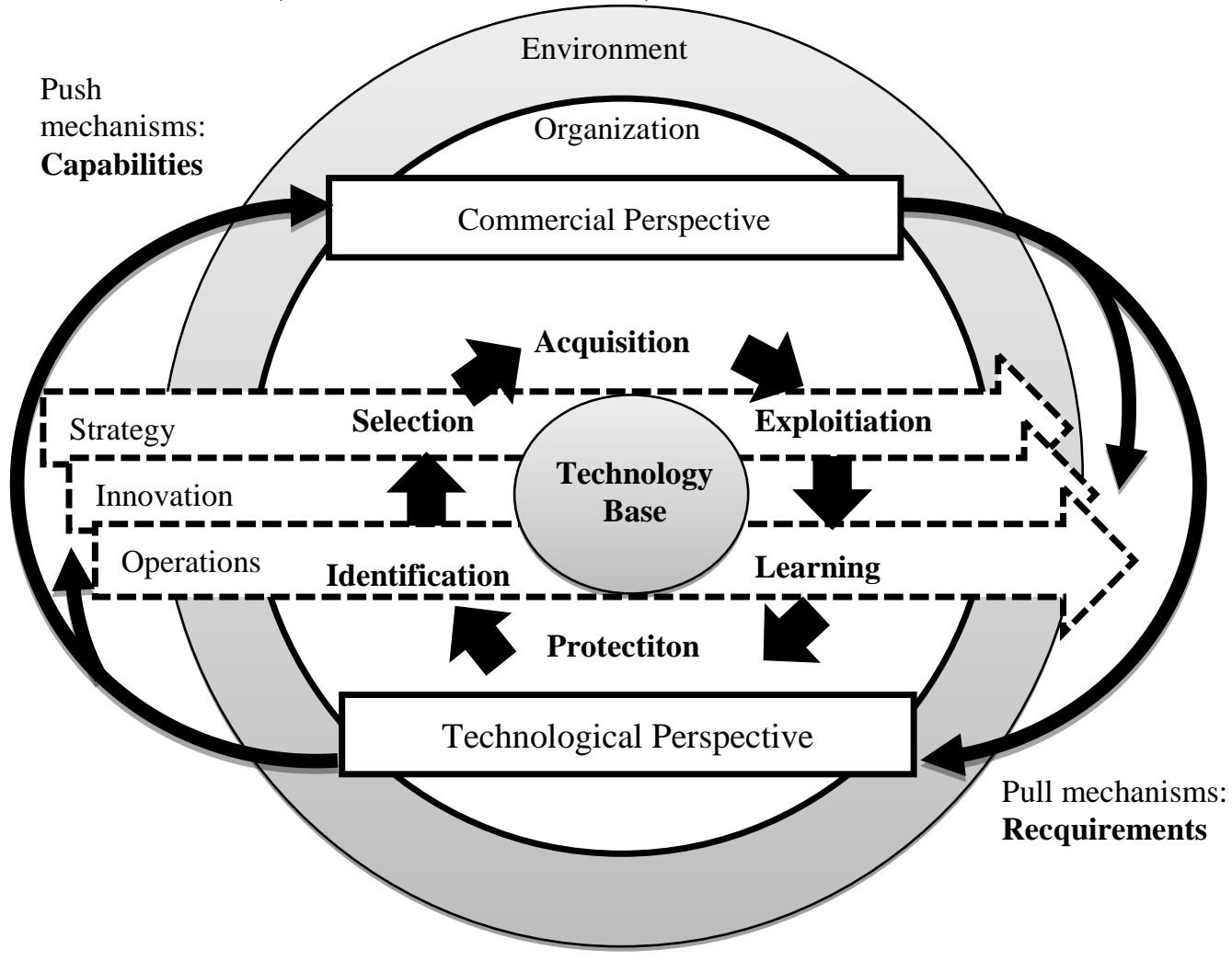

Figure 1. Technology Management Framework

(Adapted from Phaal et al., 2004; Cetindamar et al., 2010)

By providing these activities that are in line with the dynamic capabilities framework (Cetindamar et al., 2010; Phaal et al., 2004), technological capabilities can be synchronized with changing technological environment, requirements and context.

Technological capability of the firm, (as a part of the dynamic capability) is the ability to implement technological sources (patents, skilled engineers, knowledge, designs etc) to offer new 
products (Afuah, 2002; Wind \& Mahajan, 1997). According to the research by Song et al (2005), technological capabilities have a higher impact on the firm performance in technology turbulence environment. Technological capability enables the firm to response rapidly changing technological development. It can be concluded that, firms are differentiated depending on their technological capabilities. And the quality of the technological capability of the firm is a critical factor for escaping Red Queen Effect.

Barnett and Pontikes (2006) concluded that dynamic capabilities are shaped and limited through „Red Queen” competition. Competition triggers adaptive learning among organizations and make them more viable. For this effect, they compete more strongly, which in turn triggers adaptive learning in their rivals. Organizations perform to become well suited to the business context where they compete in order to adapting to competition. But, when an organization attempts to move into an unfamiliar territory, their context disrupted and the new context may be hazardous. In this way, Red Queen competition contextualizes dynamic capabilities, limiting their effective scope (Barnett $\&$ Pontikes, 2006).

In complex business environment, firms unlikely to get a specific formula to receive persistent success (Wind \& Mahajan, 1997). As discussed in previous section, Comfort Trap of Red Queen is a threat that complicates the innovators keeping up their position in the market. There are many examples of the imitators/competitors have profited more than the innovators in the market. Innovators (or incumbents) develop technologically competitive and successful products and commercialize them; but new entrants imitate and transport the assets that drive the innovation, then the incumbents are trapped and lose their market share (Teece, 1986). „Innovators' dilemma” argued by Christensen (1997) defines such a situation of this trap. Incumbent firms fail to respond to disruptive innovations since they are well focused on the margin opportunities and on existing customers too much. Especially the senior managers of the incumbents are missing to watch disruptive innovation because their views are entrenched by the current market positions. The nature of the embedded organizational competencies of the established firms hinders the effective respond to disruptive innovation (Henderson, 2006). Established firms generally have effective routines for searching current market and they establish a good perception of their current customers. Focusing much on their current customers hinders the established firms to see other opportunities.

Addition to this trap, Christensen and Raynor (2003) has argued that established firms could and should react to disruptive innovation. Firms should anticipate the potential changes, opportunities or destructions that new technologies led in the market. But, in which way do the firms be aware of the other opportunities and developing technologies?

Anticipating of the technological change and its effects in the business environment is discussed in technology management discipline. The current technology management framework offers Identification activity that refers to Technology Intelligence. Technology intelligence provides the firm to be aware of the technological environment in the meaning of two objectives. First, it provides the firm to identify the existing technologies whether they could have new applications or new marketing areas. And second, to sniff the potential technological development in the future and its direction. Consequently, for escaping the Red Queen Effect and the comfort trap discussed in previous section, technology intelligence is a critical activity that is offered by technology management discipline.

\section{Technology Intelligence}

Such systematic approaches on technology intelligence are generated and called in different terms in past researches: Technology Intelligence, Technological Environmental Scanning, Technology Scanning, Technology Oriented Competitive Intelligence, Technology Watch, and Technology Monitoring. „Technology Intelligence” is the more consistent term in literature.

Technology Intelligence is shaped through the understanding and perceiving of the nature of technological change. Technological change is relatively continuous process which casts shadows 
far ahead. These shadows are cast in more and more tangible form as an innovation is adapted for economic use. In this point of view, technological innovation is evident a long before the technology is in use. The indications of technology change and at what point to take action must be clearly found out (Utterback \& Brown, 1972).

Savioz defines Technology Intelligence as ,activities that support decision-making of technological and general management concerns by taking advantages of a well timed preparation of relevant information on technological facts and trends (opportunities and threats) of the organization's environment by means of collection, analysis and dissemination" (Savioz, 2002).

Technology Intelligence sometimes called as Technology Watch or Monitoring, in the same meaning, deals mainly with one question: Are there potential opportunities and threats in the technological environment? To answer this question, each employee contributes with knowledge building during daily work (Savioz, Luggen, Tschirky, 2003). That is to observe the technological change in a systematic way, which could be done through technology monitoring or watching. Porter et al defines technology monitoring as a technology analysis process: „Technology monitoring (also known technology watch or environmental scanning- cataloguing, characterizing, and interpreting technology development activities." (Porter \& Cunningham, 2005). Mortara et al. (2010) defines the technology intelligence as the activity dedicated to capturing important technological information and delivering it into decision makers.

Bright deals with technology monitoring in 1970, „to anticipate innovation, the political, social and other factors influencing its progress must be systematically monitored" and defines the technology intelligence in context of four activities (Bright, 1970).

The approach of „signals” also defines by Utterback and Brown in 1972 and stated that monitoring technological development has two fundamental activities (Utterback \& Brown, 1972). The signals or trend of objective observations on technological change could thus be used in managerial decisions relating to technologies in more objective manner. Technological information should be early enough to make the right decisions is critical, especially the firm has an objective to maintain high level innovation and competitive advantage (Mortara et al., 2010).

Fundamentally, the literature on technology intelligence consists of the description of the process formulated by Ashton et al. (1991). This process represents rather formalistic view of the technology intelligence process, including the acquisition (both, broad scanning and in-depth monitoring), valuation, and communication of technology-relevant information. However, their process seems to be over-formalized and not able to cope with a highly dynamic environment (Bucher et al., 2003). Kerr et al. (2006) also offered a conceptual model for technology intelligence including framework, system and process level. McGonagle (2007) concludes a classical model of competitive intelligence is considered as composed of five major steps.

At organizational basis, many ways to promote the technology intelligence are exist according to the firm' organizational structure and needs. Several ways to develop and implement technology intelligence activities, depending upon the business's environment, the uncertainty level, the strategy followed and the resources controlled (Savioz et al., 2003).

Whichever or whomever it is carried out, effective technology intelligence should be conducted by the organizations (firms, governments or other strategic societies) as a part of the strategies in short or long run. Application procedures or suggested methods in literature that are being developed could be adapted to organization culture and business habits of the firm.

\section{Result}

The result or expected outcome of the Technology Intelligence is the identification of a need to establish new technological capabilities that enables firm to evolve faster and to respond to coming technological change and its shocks.

As explained in 2nd section, technological capability enables the firm to response rapidly changing technological development. Therefore, an effective technology intelligence process triggers to build the critical and necessary technological capabilities of the firm in order to compete 
under Red Queen Effect. In the other words; a firm' business success against the Red Queen Effect is related to its effective technology intelligence activities.

As this phenomenon is realized, it enables us to discuss the efficiency of technology intelligence activity by the meaning of its speed and the quality of the knowledge created in organization.

The efficient technology intelligence activity should provide those expected benefits for the organization to run faster and smarter than their competitors under Red Queen Effect environment:

1) Systematically and continuously searching out new technologies, markets, business opportunities and customers.

2) Exploring the new sources to exploit for technology and business development.

3) Identifying new research and development paths for the organization and helping to evaluate its long and short term strategies.

4) Increasing the useful knowledge for the organization and decreasing the unexploited information volume.

The keywords are „systematic” and „continuous”. Technology intelligence is not a point in the time horizon; but a continuous process embedded into the organization's routines, operations and policy. Therefore, organization could be aware of the signals of the changing technologies and the business environment. The signal sensing makes the organization (1) to identify its needs to create or to develop the new technological capability to compete, and (2) to absorb the exterior information to create the knowledge in the organization continuously. It makes the organization different and smarter than the others.

Let's see the successful technology intelligence applications from the sectors where the Red Queen Effect has a great pressure on the companies, such as Information and Communication sector. In this area, there have been so many disruptive technological developments and companies are facing disruptive threats (Latzer, 2009). The cannibalisation in this sector is a result of Red Queen Effect; in literature there are cases about the incumbent companies do not react in time against the replacing and disruptive technologies. For example; Western Union, the telegraphy incumbent was acquired by a telephone startup company AT\&T. On the other hand, in Information and Communication sector, there are also successful examples of technology intelligence against the Red Queen Effect.

Motorola, the leading company in mobile communication services, had a formal technology intelligence program that was established in 1940s. Motorola became a technology oriented company by its successful technology intelligence program that was carried out by dedicated personnel and a great budget. Based on its technology intelligence, Motorola had a great motivation to seize the technology-based opportunity before any of its competitors could. They scanned Motorola's many competitors, looking for any signals of satellite communication programs and also other sectors, defense and space especially. They checked also governments' actions in US and Europe. Patents, scientific publications were also under their following. As a result, Motorola management put an early decision for a new business -Iridium which was very new and some more risky project (Norling et al., 2000). Iridium was a system of many active satellites used for worldwide voice and data communication from hand-held satellite phones and other transceiver units. It was new to world that people can communicate each other anywhere and anytime in the world.

Deutsche Telekom is represented in about 50 countries worldwide and is one of the world's leading telecommunications and information technology companies. In Deutsche Telekom Laboratories, technology intelligence activities are conducted based on a tool named Technology Radar. Rohrbeck et al. (2006) discussed that the technology intelligence activities with this tool has increased the Deutsche Telekom Laboratory's ,absorptive capacity” since it enables the employees to access to and to be aware of the different topics. Addition to this factor, technology intelligence activities in Deutsche Telekom have lead to the ,proposal of five new R\&D projects" at Deutsche Telekom Laboratories.

The systematic and continuous technology intelligence as a part of the technology 
management activities of the company is also related with the co-evolution of the intelligence activities of the companies. There shall be reciprocal intelligence activities among the rivals. Peltoniemi and Vuori (2005) discussed that effective intelligence activity spurs the co-evolution of the intelligence activities between the companies. Intelligence activity provides the information about the firms' new developments to each other. And this leads Red Queen Effect. The organisations are willing to invest in developing intelligence activities as a response to the intelligence activities of the competitor. As a result; Red Queen Effect feeds the effective technology intelligence activities between the rivals.

\section{Discussion}

This paper presents an important connection between Red Queen Effect and Technology Intelligence of the organizations in order to answer the question ,how to be faster and smarter" in competitive business environment. Technology intelligence is offered as a necessary and effective activity that is a part of the technology management process against the Red Queen Effect and its comfort trap.

There are specific and disruptive moves and countermoves of the rivals in recent years in many sectors. These moves feed the rapid technological developments, and spur the companies to seize the recent technological capabilities and to build the new ones. In this knowledge based business environment, efficient technology intelligence activities make the firm different than its competitors since it offers a systematic and continuous awareness of new technologies, markets, new sources to exploit and new paths to follow. Addition to these, technology intelligence provides the useful information according to the identified ,need" and decreases the unexploited information volume in the organization. With these advantages, organization can put effective decisions before the rivals and execute them more efficiently under Red Queen dynamism.

A significant implication for the future research is that, efficiency of the technology intelligence is an important parameter for escaping the Red Queen Effect. The efficiency of the technology intelligence process may be shown as a case study research addition to this paper.

\section{References}

Afuah, A. (2002). Research Notes and Commentaries, Mapping Technological Capabilities Into Product Markets And Competitive Advantage: The Case of Cholesterol Drugs. Strategic Management Journal, Vol: 23, pp. 171-179. http://dx.doi.org/10.1002/smj.221

Aguilar, F. J. (1967). Scanning Business Environment, The Macmillan Co. Publishing, New York.

Ashton, W. B., Kinzey, B. R. \& Gunn, M. E. (1991). A Structural Approach For Monitoring Science and Technology Developments. International Journal of Technology Management, Vol: 6 (1/2), pp. $91-$ 111.

Barnett W. P., McKendrick, D. G. (2004). Why Are Some Organizations More Competitive Than Others? Evidence from a Changing Global Market. Administrative Science Quarterly, Vol: 49 pp. 535-571.

Barnett, W. P., Pontikes, E. G. (2005). The Red Queen, Success Bias, and Organizational Inertia. Harward Business School Strategic Management Conference, October.

Barnett, W. P., Sorenson, O. (2002). The Red Queen In Organizational Creation and Development. Industrial and Corporate Change, Volume 11, Number 2, pp. 289-325. http://dx.doi.org/10.1093/icc/11.2.289

Barnett, W. P., Hansen, M. T. (1996). The Red Queen in Organizational Evolution. Strategic Management Journal, 17, pp: 139-157. http://dx.doi.org/10.1002/smj.4250171010

Baumol, W. J. (2004). Red-Queen Games: Arms Races, Rule of Law and Market Economies. Journal of Evolutionary Economics, Vol: 14, pp. 237-247. http://dx.doi.org/10.1007/s00191-004-0207-y

Bright, J. R. (1970). Evaluating Signals of Technological Change. Harward Business Review, January February, pp. 62- 70. 
Bucher, P., Birkenmeier, B., Brodbeck, H., Ecsher, J. P. (2003). Management Principles for Evaluating and Introducing Disruptive Technologies: The Case of Nanotechnology In Switzerland. $R \& D$ Management, Vol: 33-2, pp. 149-163.

Carroll, L. (1872). Through the Looking-Glass, and What Alice Found There. Macmillan \& Co., London.

Cetindamar, D., Phaal, R., Probert, D. (2010). Technology Management Activities and Tools. Palgrave Publishment, New York.

Christensen, C., Raynor, M. (2003). The Innovator's Solution. Harvard Business School Press, Boston.

Christensen, C. (1997). The Innovator's Dilemma. Harvard Business School Press, Boston.

Cooper, A. C, Schendel, D. (1976). Strategic Responses to Technological Threats. Business Horizons, Vol: 16, pp. 61-69. http://dx.doi.org/10.1016/0007-6813(76)90024-0

Edler, J., Krahmer, F. M, Reger, G. (2002). Changes In The Strategic Management of Technology: Results of A Global Banchmarking Study. R\&D Management, Vol: 32-2, Blackwell Publishing, pp. 149-164.

Ehrlich, P. R. \& Raven, P. H. (1964). Butterflies and Plants: A Study in Co-evolution. Evolution, Vol. 18, pp. 586-608. http://dx.doi.org/10.2307/2406212

Gregory, M. J. (1995). Technology Management: A Process Approach. Proceedings of the Institution of Mechanical Engineers, Vol: 209, pp: 347-356. http://dx.doi.org/10.1243/PIME_PROC_1995_209_094_02

Henderson, R. (2006). The Innovator's Dilemma as a Problem of Organizational Competence. The Journal of Product Innovation Management, 23: 5, pp. 5-11. http://dx.doi.org/10.1111/j.1540-5885.2005.00175.x

Kaufman, S. A. (1995). Technology and Evolution: Escaping Red Queen Effect. The Mckinsey Quarterly, No: 1, pp.119-129.

Kerr, C. I. V., Mortara, L,. Phaal, R, Probert, D. R. (2006). A Conceptual Model For Technology Intelligence. International Journal of Technology Intelligence and Planning, Vol: 2, No: 1, pp. 73-93. http://dx.doi.org/10.1504/IJTIP.2006.010511

Latzer, M. (2009). Information and Communication Technology Innovations: Radical and Disruptive? New Media \& Society, Vol 11(4), pp. 599-619. http://dx.doi.org/10.1177/1461444809102964

Lichtenthaler, E. (2003). Third Generation Management of Technology Intelligence Processes. $R \& D$ Management, Vol: 33-4, Blackwell Publishing, pp. 361-375.

Lichtenthaler, E. (2005). The Choice of Technology Intelligence Methods in Multinationals: Towards a Contingency Approach. International Journal of Technology Management, Vol: 32, Nos. 3/4, pp. 388407. http://dx.doi.org/10.1504/IJTM.2005.007341

Lichtenthaler, E. (2006). Managing Technology Intelligence Processes in Situations of Radical Innovation Change. Technological Forecasting and Social Change, No: 74, pp. 1109-1136.

McGonagle, J. J. (2007). An Examination of the 'Classic' CI Model. Journal of Competitive Intelligence and Management, Volume 4, No.2, pp:71-86.

Mortara, L., Thomson, R., Moore, C., Armara, K., Kerr, C., Phaal, R., Probert, D. (2010). Developing a Technology Intelligence Strategy at Kodak European Research: Scan and Target. Industrial Research Institute, July-August Edition.

Norling, P. M., Herring, J. P., Rosenkrans, W. A., Stellpflug, M., Kaufmann, S. B (2000). Putting Competitive Technology Intelligence To Work. Research Technology Management, Sep/Oct, 43, 5, pp: 23-25.

Pagie, L., Hogeweg, P. (2000). Information Integration and Red Queen Dynamics In Co-evolutionary Optimization. Proceedings of the 2000 Congress on Evolutionary Computation, pp. 1260-1267. http://dx.doi.org/10.1109/CEC.2000.870795

Peltoniemi, M., Vuori, E. (2005). Competitive Intelligence and Co-Evolution within an Organization Population. Proceedings of the 6th European Conference on Knowledge Management (ECKM 2005), September 8-9, Limerick, Ireland.

Phaal, R., Farrukh, C. J. P., Probert, D. R. (2004). A Framework Supporting the Management of Technological Knowledge. International Journal of Technology Management, Vol: 27, No: 1, pp.1-15. http://dx.doi.org/10.1504/IJTM.2004.003878

Porter, A. L., Cunningham, S. W. (2005). Tech Mining: Exploiting New Technologies for Competitive Advantage. Wiley \& Sons Inc., New Jersey. 
Rohrbeck, R (2007). Technology Scouting - a Case Study on the Deutsche Telekom Laboratories. ISPIMAsia Conference, New Delhi.

Rohrbeck, R, Heuer J, Arnold H. (2006). The Technology Radar - an Instrument of Technology Intelligence and Innovation Strategy. The 3rd IEEE International Conference on Management of Innovation and Technology; 2006; Singapore, pp. 978-983. http://dx.doi.org/10.1109/ICMIT.2006.262368

Savioz, P. (2002). Technology Intelligence in Technology-Based SMEs: Conceptual Design and Implementation. ETH Zürich, B-327422, Verlag Industrial Organization.

Savioz, P., Luggen, M., Tschirky, H. (2003). Technology Intelligence- Structuring It Into The New Technology Based Firm (NTBF). Tech Monitor, July-August, pp. 41-46.

Schumpeter, J. (1934). The Theory of Economic Development. Cambridge, Mass, Harvard University Press, (sixteenth press, reprinted in 2012).

Schumpeter, J. A. (1976) Capitalism, Socialism, and Democracy (5th ed.). London: George Allen \& Unwin (the e-library edition by Taylor \& Francis in 2003).

Smith, A. (1776) An Inquiry into the Nature and Causes of the Wealth of Nations. 2 vols. Reprinted in 1981, Indianapolis, IN: Liberty Press.

Song, M., Cornelia, D., Snagphet, H., Calantone, R. (2005). Marketing and Technology Resource Complementarity: An Analysis of Their Interaction Effect in Two Environmental Contexts. Strategic Management Journal, Vol: 26, pp. 259-276. http://dx.doi.org/10.1002/smj.450

Teece, D. J. (1986). Profiting From Technological Innovations: Implications for Integration. Collaboration, Licencing and Public Policy, Research Policy, vol: 15, pp. 285-305.

Teece, D., Pisano, G., \& Shuen, A. (1997). Dynamic Capabilities and Strategic Management. Strategic Management Journal, 18(7), pp.509-533. http://dx.doi.org/10.1002/(SICI)10970266(199708)18:7<509::AID-SMJ882>3.0.CO;2-Z

Tripsas, M. (1997). Surviving Radical Technological Change Through Dynamic Capability: Evidence From The Typesetter Industry. Industrial and Corporate Change, Vol: 6, No: 2, pp: 341-377. http://dx.doi.org/10.1093/icc/6.2.341

Utterback, J. M. \& Brown, J. W. (1972). Profiles of the Future: Monitoring For Technological Opportunities. Business Horizons, Vol: 15, pp. 5-15. http://dx.doi.org/10.1016/0007-6813(72)90042-0

Van Valen, L. (1973). A New Evolutionary Law. Evolutionary Theory, 1, pp. 1-30.

Voelpel, S., Leibold, M., Tekie, E., Krogh, G. V. (2005). Escaping the Red Queen Effect In Competitive Strategy: Sense-Testing Business Models. European Management Journal, Vol. 23, No. 1, pp. 37-49. http://dx.doi.org/10.1016/j.emj.2004.12.008

Wind, J., Mahajan, V. (1997). Issues and Opportunities In New Product Development: An Introduction To The Special Issue. Journal of Marketing Research, Vol: 34, pp.1-12. http://dx.doi.org/10.2307/3152060 